九州大学学術情報リポジトリ

Kyushu University Institutional Repository

\title{
The Effects of SPS Measures on The Duration of China's Agroproduct Exports
}

ZHANG, Xiaoqi

College of Economics and Management, Nanjing Agricultural University

MAEDA, Koshi

Department of Agricultural and Resource Economics, Faculty of Agriculture, Kyushu University

WANG, Xue jun

College of Economics and Management, Nanjing Agricultural University

https://doi.org/10.5109/4363562

出版情報：九州大学大学院農学研究院紀要. 66 (1)，pp. 145-153，2021-03-01. Faculty of Agriculture, Kyushu University

バージョン:

権利関係： 


\title{
The Effects of SPS Measures on The Duration of China's Agroproduct Exports
}

\author{
Xiaoqi ZHANG ${ }^{1}$, Koshi MAEDA and Xuejun WANG ${ }^{1 *}$ \\ Laboratory of Quantitative Food Economic Analysis, Division of Agricultural and Resource Economics, \\ Department of Agricultural and Resource Economics, Faculty of Agriculture, \\ Kyushu University, Fukuoka 819-0395, Japan \\ (Received October 30, 2020 and accepted November 4, 2020)
}

\begin{abstract}
Using trade data for 6-digit HS code agroproducts of China's exports for 2002 and 2017, we investigate how SPS measures set by importing countries impact the duration of Chinese agricultural exports via discrete time survival analysis. The results show that SPS measures imposed by importing countries have a significant negative impact on the export duration of China's agroproducts, which increases the survival risks of agricultural exports. In addition, different SPS measures have different impacts. SPS measures adopted for reasons of food safety, plant protection, and humans protections from animal and plant pests and diseases have a more significantly negative impact on export duration, and regular notification is more likely to interrupt China's agricultural exports than emergency notification.
\end{abstract}

Key words: Agroproducts, Export duration, SPS, Survival analysis

\section{INTRODUCTION}

Agricultural exports have always played a crucial role in China's trade networks. However, China, a large agricultural exporter of products, does not sustain its agricultural exports, and the median survival period is only two years (Chen et al., 2012). Over 50\% of export duration disappears within two years. As evidenced by existing research, sustained and increasing exports are a major driver of export growth (Besedeš and Prusa, 2011). Excessively short export durations resulting from exporters' frequent entry into and exit from the export market interrupt the continuity of agricultural exports on the one hand and, destabilize trade relationships and weaken the responses of China's agricultural exports to external shocks on the other. Thus, clarifying the factors related to the export duration of China's agroproducts is essential to stabilizing agricultural exports.

Due to its unique features, agricultural trade is typically impacted by the "sanitary and phytosanitary measures" (SPS measures) of importing countries due to general trade cost increases. SPS measures are the main non-tariff measures imposed on agroproducts under the WTO framework. Importing countries establish SPS measures to set thresholds of product quality, and compliance costs will first impact enterprises' market access behaviours, which take a toll on trade flows (Shang and Tonsor, 2019). An excessively high compliance cost can have effects equivalent to those of a trade embargo by interrupting trade ties (Wilson and Otsuki, 2004; Aka, 2017), thus resulting in a very short export duration. After China's entry into the WTO, the number of SPS notifications affecting China's agricultural trade

\footnotetext{
${ }^{1}$ College of Economics and Management, Nanjing Agricultural University, Nanjing 210095, China

* Corresponding author (E-mail: wangxj@njau.edu.cn)
}

increased annually from 2002 to 2017, reaching a total of 6,543. At the same time, Chinese agricultural exports grew more gradually each year and the agricultural trade deficit continued to widen. SPS measures imposed on China's agricultural exports are characterized by consideration of a large number of countries, strict standards, and a wide range of products. These measures seriously hamper the progress of Chinese agricultural export. Different from other trade barriers resulting from rising trade costs, SPS measures can directly interrupt agricultural exports, which may become a major cause of the short China's agricultural export durations.

Scholars abroad have studied the impacts of SPS measures on the export duration of agroproducts. For instance, Peterson et al. (2018), on the basis of data on vegetable and fruit exports to the US for 1996 and 2008, analysed the impact of American SPS measures on export duration. The results show that SPS measures had an enduring negative impact on export duration, but the impact declined over time. Most existing research focuses on the impact of SPS measures on China's agricultural exports from trade flows, export dual margins, and export probability (Henson and Loader, 2001; Crivelli and Groeschl, 2016; Gibson and Wang, 2018), but their impacts on export duration are not yet clear. In particular, no research has examined the impacts of SPS measures on the export survival of China's agroproducts. Thus, further work is needed on the impacts of SPS measures adopted by importing countries on the survival of exports of China's agroproducts.

Existing empirical research on export duration covers two areas. First, this work describes dynamic changes and distribution features of export duration using the survival analysis method (Besedeš and Prusa, 2006b; Brenton et al., 2010; Asche et al., 2018). Second, such work presents empirical analyses of export duration factors (Nitsch, 2009). Due to limitations, this paper, in combining SPS and export duration, studies 
the dynamic distribution of export duration and corresponding export survival probability after China's accession to the WTO, and further analyses whether the reported SPS is a major cause of the short duration of China's agricultural exports. The paper concludes that SPS measures imposed by importing countries significantly impact the likelihood of the survival of China's agricultural exports, shorten export durations, and interrupt export relationships. Furthermore, this impact varies significantly across different products, countries and SPS measures.

\section{DESCRIPTIVE ANALYSIS OF THE DURATION OF AGRICULTURAL EXPORTS}

This paper constructs a survival function for agricultural exports to describe the dynamic export duration of agroproducts.

In the study of export duration, one common censoring problem must be addressed. Censoring includes left and right censoring. Left censoring refers to a trade duration that exists before a sample is observed. In this case, the start time is unknown. Data with this feature are called left-censored data. Likewise, right censoring refers to a trade duration that continues after the sample observation period ends. In other words, the trade relationship continues but its duration is unknown. Data with this feature are called right-censored data. For the solution of the left censoring problem, we, based on existing research (Chen et al., 2012), remove the observed value with the left-censoring problem, and remove the trade duration from the start year of 2002 for sample observations. Thus, the trade duration lasts 15 years from the earliest year of 2003. The right-censoring problem can be solved with the following survival analysis method.

Assume $\mathrm{T}$ is the time of the failure incident, $t_{i}$ is the discrete random variable, where $i=1,2, \ldots, \mathrm{n}$, then the probability density function is $\mathrm{p}\left(t_{i}\right)=\operatorname{Pr}\left(\mathrm{T}=t_{i}\right), i=1,2$, $\ldots, \mathrm{n}$, and $t_{1}<t_{2}<\ldots<t_{n}$. Then the survival function of the random variable $\mathrm{T}$ is:

$$
\mathrm{S}(\mathrm{t})=\operatorname{Pr}(\mathrm{T}>\mathrm{t})=\sum_{t_{i}>t} p\left(t_{i}\right)
$$

The hazard function is given by:

$$
\mathrm{h}\left(t_{i}\right)=\operatorname{Pr}\left(\mathrm{T}=t_{i} \mid \mathrm{T} \geq t_{i}\right)=\frac{p\left(t_{i}\right)}{S\left(t_{i-1}\right)}
$$

And with $\mathrm{S}\left(t_{0}=1\right)$, the survival function and the hazard function have the following relationship:

$$
\mathrm{S}(\mathrm{t})=\prod_{t_{i}<t}\left[1-h\left(t_{i}\right)\right]
$$

According to the research of Besedeš and Prusa (2006a), the Kaplan-Meier product-limit estimator can use all the information of the right censored data and the non-right censored data, and it is robust to the right censored data. Thus, the Kaplan-Meier non-parametric method can be used to estimate the survival function and risk function.

In practice, the survivor and hazard functions are estimated (non-parametrically) by computing the num- ber of spells that survive (fail) as a fraction of the total number of spells that are at risk after $t_{(i)}$ periods. We assume that there are $n$ independent observations ( $t_{i}$, $\left.c_{i}\right), i=1,2, \ldots, \mathrm{n}$, where $t_{i}$ is the survival time and $c_{i}$ is the censoring indicator variable of the observation $i$. If a "failure event" occurs, then the value of $c_{i}$ is 1 , otherwise the value of $c_{i}$ is 0 . For a dataset with observed failure times, $t_{(1)}<t_{(2)}<\ldots<t_{(m)}$, and $\mathrm{m} \leqslant \mathrm{n}$, where $n_{i}$ is the number of distinct failure times observed in the data, the Kaplan-Meier product limit estimator of the survivor function is:

$$
\hat{S}(t)=\prod_{t(i)<t} \frac{n_{i}-d_{i}}{n_{i}}
$$

where $n_{i}$ is the number of spells at risk at time $t_{(i)}$ and $d_{i}$ is the number of failures at time $t_{(i)}$. The product is over all observed failure times less than or equal to $t$. Similarly, a non-parametric estimation of the hazard function is given by the ratio of spells who fail to the number of spells at risk in a given period $t$.

$$
\hat{h}(t)=\frac{d_{i}}{n_{i}}
$$

Based on the Kaplan-Meier product-limit estimation equation, with data on China's agricultural exports for 2002 and 2017, we conduct an overall estimation, importer estimation, and product category estimation of the export survival function, to directly describe and analyse the export duration of agroproducts. In real trade settings, product $i$ may exit the market on the way to destination country $j$, and enters country $j$ later on, forming several duration stages of the trade relationship. Based on past experience, the different duration stages of a trade relationship are independent from each other.

Figure 1 shows the survival function estimation based on all samples: first, the export duration of agroproducts is generally short, the median survival time is one year, and approximately $60 \%$ of the duration will disappear within one year; second, the trade relationship of agroproducts starts with relatively a low survival probability, and the failure probability of the trade relationship then significantly decreases. The data analysis shows that the survival probability over one to five years decreases from $40 \%$ to below 20\%, representing a decrease of $20 \%$; the survival probability over six to ten years drops from $20 \%$ to $10 \%$, representing a decrease of $10 \%$. Thus, one consistent conclusion can be drawn: the failure probability of one trade relationship shows negative duration dependence and thus, an obvious "threshold effect". In this paper, the "threshold value" of the survival time is five years, i.e. the failure risk of a trade duration of five years or longer will significantly decrease.

To study the impact of SPS measures on the export duration of China's agroproducts, we conduct grouped estimation based on whether a product is reported to show SPS problems by importing countries. The estimated result provided in Figure 2 shows that survival probability significantly differs between the reported agroproducts and the non-reported ones. The survival 


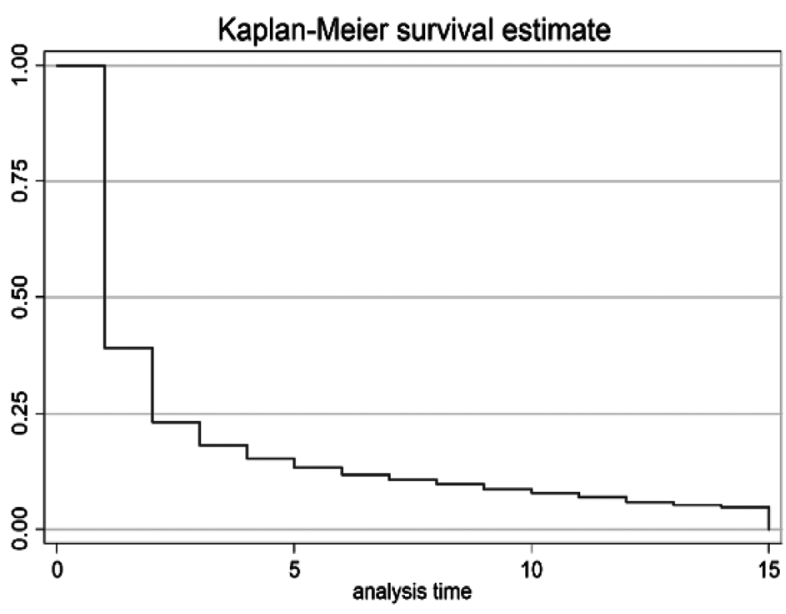

Fig. 1. Total agricultural product export survival function

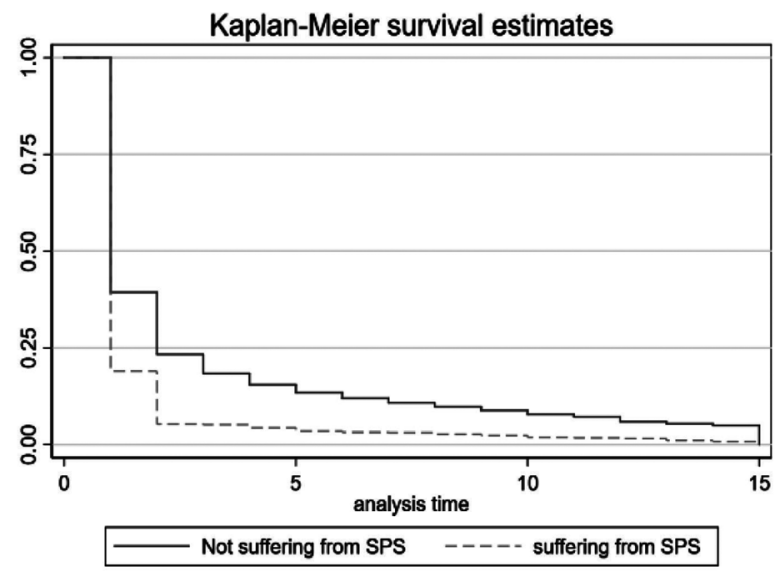

Fig. 2. Survival function: classification based on whether the product suffers from SPS

probability of agroproducts with reported SPS problems by importing countries is much lower than that of the products not reported. The survival probability of agroproducts drops to below 10\% two or three years after they are reported, proving that SPS measures imposed by importing countries on China's agroproducts significantly lower the survival probability of the exports of these products and even interrupt trade relationships.

\section{THE IMPACT OF SPS MEASURES ON THE SURVIVAL OF CHINA'S AGRICULTURAL EXPORTS}

\section{Estimation strategy}

Hess and Persson (2011) pointed out that when studying the impact factors of trade duration, the discrete-time generation analysis model is more suitable than the risk-based model. In order to estimate the parameters of the separation time survival analysis model, we first need to set up the function form of the risk rate of the enterprise-product pair $m$ in period $t$.

This article refers to the method of Chen et al. (2012) to construct the country-product pair in the discrete time cloglog survival analysis model of $t$ time period. The following estimation specification is used to study the impact of SPS measures on China's agricultural exports at the HS-6 digit product level:

$$
y_{o k t}=\alpha+\beta S P S_{o k t}+\lambda C_{k t}+\delta P_{o t}+u_{o}+u_{k}+u_{t}+\varepsilon_{o k t}
$$

where $y_{\text {okt }}$ is the outcome variable for product $k$ export to country $o$ in year $t$. According to the rules of survival analysis, $y_{\text {okt }}$ equals one if China ends a trade spell of commodity $k$ to country $o$ in year $t$, and zero otherwise; $S P S_{\text {okt }}$ is a dummy variable taking the value of 1 if product $k$ exported to country $o$ in year $t$ suffered from SPS measures reported by country $o$ and 0 otherwise; The coefficient, $\beta$ therefore indicates the impact of SPS measures on the dependent variables. A positive and significant $\beta$ suggests that SPS measures exerts a negative effect on China's duration of China's agricultural exports, while a negative and significant $\beta$ indicates that SPS measures pushed China's agricultural exports continue. $C_{k t}$ and $P_{o t}$ contain a series of product-level and country-level characteristic variables that may affect the duration of product exports: ln $(g d p)$ represents the economic scale of the export destination country $O$; (EXR) represents the exchange rate fluctuations of the destination country $O$, expressed by the change in the log value of the exchange rate of the destination country to the US dollar; tradevalue is the total export value of agricultural products $k$ exported by China in year $t$; per value is the per capita trade volume of country $o$, used to measure the per capita demand for product $k$ in country o; and $N \_$product means the number of product categories that China exported to country $o$ in year $t ; N_{-}$ country is the number of destination countries for China's export product $k$ in year $t$; percent_value is the proportion of the trade volume of product $k$ that China exported to country $o$ in year $t$ in the total export volume of China. The country-specific dummy variable $u_{\circ}$ controls for time-invariant, unobserved country characteristics that shape exports from China to other countries. $u_{k}$ is the product dummy capturing all time-invariant product characteristics, $u_{t}$ is the year dummy capturing effects common to all products in the same year, and $\varepsilon_{o k t}$ is an error term.

\section{Data}

The data used in this article are drawn from two sources. (1) SPS information are taken from the SPS/ IMS WTO website, which provides SPS data reported by each country, including product codes, notification reasons, notification years, affected countries, etc. (2) We obtain annual trade data from UN Comtrade for the 2002-2017 period. The dataset includes the trade value and trade volume of products and the export destination country for each year. For years with no trade data, it is assumed that China's agricultural exports in these years were interrupted. We match these two databases at the HS-6 product level. To perform our duration analysis, we translate yearly trade data into trade relationships and spells of service. A trade relationship is defined as a HS-country pair while a spell of service consists of consecutive years during which a trade relationship is 
active. In the case of multiple spells, a trading relationship can stop and be re-established once or several times over the study period after an interruption of one or more years. In our dataset, some of the trading rela-

Table 1. Descriptive statistics of the duration of China's agricultural exports from 2002 to 2017

\begin{tabular}{cccc}
\hline Duration & Number & Percentage & $\begin{array}{r}\text { Cumulative } \\
\text { proportion }\end{array}$ \\
\hline 1 & 29093 & $49.00 \%$ & $49.00 \%$ \\
2 & 10087 & $16.99 \%$ & $65.98 \%$ \\
3 & 4127 & $6.95 \%$ & $72.93 \%$ \\
4 & 2437 & $4.10 \%$ & $77.04 \%$ \\
5 & 1718 & $2.89 \%$ & $79.93 \%$ \\
6 & 1286 & $2.17 \%$ & $82.10 \%$ \\
7 & 993 & $1.67 \%$ & $83.77 \%$ \\
8 & 880 & $1.48 \%$ & $85.25 \%$ \\
9 & 838 & $1.41 \%$ & $86.66 \%$ \\
10 & 864 & $1.46 \%$ & $88.12 \%$ \\
11 & 641 & $1.08 \%$ & $89.20 \%$ \\
12 & 1111 & $1.87 \%$ & $91.07 \%$ \\
13 & 481 & $0.81 \%$ & $91.88 \%$ \\
14 & 442 & $0.74 \%$ & $92.62 \%$ \\
15 & 4381 & $7.38 \%$ & $100.00 \%$ \\
Total & 59379 & & $100.00 \%$ \\
\hline
\end{tabular}

Data source: The author compiled according to UN Comtrade database tionships show multiple spells. For this exercise, we treat multiple spells as independent cases. We identify yearly HS-country observations that map into 77112 spells of service reflecting 59379 trade relationships, as shown in Table 1.

\section{RESULTS}

In this section, we first provide the baseline empirical findings regarding how the duration of China's agriculture exports respond to SPS measures. We then present a series of robustness checks on the validity of our estimation and other econometric concerns. Finally, we conducted some heterogeneity tests.

\section{Baseline results}

Table 2 reports the results of regression using the cloglog model and the probit model. We find that SPS notification by importing countries significantly increases risks of suspension of trade relations and reduces the duration of China's agricultural exports. After gradually adding product, year, and country fixed effects, SPS measures have a more negative impact on the survival probability of agricultural exports, denoting that the survival of agricultural exports has increased. Specifically, column (1) only control the product fixed effect, and then columns (2) and (3) successively

Table 2. The impact of SPS measures on China's agricultural exports

\begin{tabular}{|c|c|c|c|c|c|c|}
\hline \multirow[b]{2}{*}{ Variables } & \multicolumn{3}{|c|}{ cloglog } & \multicolumn{3}{|c|}{ Probit } \\
\hline & $\begin{array}{c}\text { (1) } \\
\text { outcome }\end{array}$ & $\begin{array}{c}\text { (2) } \\
\text { outcome }\end{array}$ & $\begin{array}{c}\text { (3) } \\
\text { outcome }\end{array}$ & $\begin{array}{c}\text { (4) } \\
\text { outcome }\end{array}$ & $\begin{array}{c}\text { (5) } \\
\text { outcome }\end{array}$ & $\begin{array}{c}\text { (6) } \\
\text { outcome }\end{array}$ \\
\hline SPS & $\begin{array}{c}0.7091 * * * \\
(0.1520)\end{array}$ & $\begin{array}{c}0.7242^{* * * *} \\
(0.1521)\end{array}$ & $\begin{array}{c}0.7460 \text { **** } \\
(0.1531)\end{array}$ & $\begin{array}{c}0.6643^{* * *} \\
(0.1590)\end{array}$ & $\begin{array}{c}0.7071 * * * \\
(0.1590)\end{array}$ & $\begin{array}{c}0.7390 * * * \\
(0.1611)\end{array}$ \\
\hline $\operatorname{lngdp}$ & $\begin{array}{c}-0.1320 * * * \\
(0.0075)\end{array}$ & $\begin{array}{c}-0.1351^{* * *} \\
(0.0076)\end{array}$ & $\begin{array}{c}-0.3481 \text { *** } \\
(0.0918)\end{array}$ & $\begin{array}{c}-0.1162 * * * \\
(0.0063)\end{array}$ & $\begin{array}{c}-0.1180 * * * \\
(0.0064)\end{array}$ & $\begin{array}{c}-0.2094 * * * \\
(0.0784)\end{array}$ \\
\hline EXR & $\begin{array}{c}0.0006 * * * \\
(0.0002)\end{array}$ & $\begin{array}{c}0.0005 * * * \\
(0.0000)\end{array}$ & $\begin{array}{c}0.0002 \\
(0.0000)\end{array}$ & $\begin{array}{c}0.0001^{* * *} \\
(0.0002)\end{array}$ & $\begin{array}{c}0.0001 * * * \\
(0.0002)\end{array}$ & $\begin{array}{c}0.0000 \\
(0.0005)\end{array}$ \\
\hline tradevalue & $\begin{array}{c}-0.0000^{* *} \\
(0.0000)\end{array}$ & $\begin{array}{c}-0.0000 * * \\
(0.0000)\end{array}$ & $\begin{array}{c}-0.0000 * * \\
(0.0000)\end{array}$ & $\begin{array}{c}-0.0000 * * * \\
(0.0000)\end{array}$ & $\begin{array}{c}-0.0000 * * \\
(0.0000)\end{array}$ & $\begin{array}{c}-0.0000 * * \\
(0.0000)\end{array}$ \\
\hline per_value & $\begin{array}{c}0.0002 \\
(0.0002)\end{array}$ & $\begin{array}{c}0.0001 \\
(0.0002)\end{array}$ & $\begin{array}{c}0.0001 \\
(0.0002)\end{array}$ & $\begin{array}{c}0.0002 \\
(0.0002)\end{array}$ & $\begin{array}{c}0.0002 \\
(0.0002)\end{array}$ & $\begin{array}{c}0.0002 \\
(0.0002)\end{array}$ \\
\hline N_product & $\begin{array}{c}-0.0046^{* * *} \\
(0.0001)\end{array}$ & $\begin{array}{c}-0.0047^{* * *} \\
(0.0001)\end{array}$ & $\begin{array}{l}0.0012^{* *} \\
(0.0005)\end{array}$ & $\begin{array}{c}-0.0033^{* * *} \\
(0.0000)\end{array}$ & $\begin{array}{c}-0.0033^{* * * *} \\
(0.0000)\end{array}$ & $\begin{array}{c}0.0017^{* * *} \\
(0.0004)\end{array}$ \\
\hline N_country & $\begin{array}{c}-0.0202 * * * \\
(0.0003)\end{array}$ & $\begin{array}{c}-0.0210 * * * \\
(0.0003)\end{array}$ & $\begin{array}{c}-0.0228 * * * \\
(0.0003)\end{array}$ & $\begin{array}{c}-0.0152 * * * \\
(0.0002)\end{array}$ & $\begin{array}{c}-0.0158 * * * \\
(0.0002)\end{array}$ & $\begin{array}{c}-0.0173 * * * \\
(0.0003)\end{array}$ \\
\hline percent_value & $\begin{array}{c}-0.7050 * * * \\
(0.0669)\end{array}$ & $\begin{array}{c}-0.6831 * * * \\
(0.0673)\end{array}$ & $\begin{array}{c}-0.9422^{* * *} \\
(0.0700)\end{array}$ & $\begin{array}{c}-0.4050 * * * \\
(0.0434)\end{array}$ & $\begin{array}{c}-0.4013^{* * * *} \\
(0.0439)\end{array}$ & $\begin{array}{c}-0.5980 \text { *** } \\
(0.0453)\end{array}$ \\
\hline Product FE & Yes & Yes & Yes & Yes & Yes & Yes \\
\hline Year FE & No & Yes & Yes & No & Yes & Yes \\
\hline Country FE & No & No & Yes & No & No & Yes \\
\hline Constant & $\begin{array}{c}2.3121 * * * \\
(0.1170)\end{array}$ & $\begin{array}{c}2.7111 * * * \\
(0.1541)\end{array}$ & $\begin{array}{c}8.6840 * * * \\
(1.8740)\end{array}$ & $\begin{array}{c}2.4000 * * * \\
(0.0966)\end{array}$ & $\begin{array}{c}2.6712 * * * \\
(0.1251)\end{array}$ & $\begin{array}{c}5.5970 * * * \\
(1.6142)\end{array}$ \\
\hline Observations & 89,962 & 89,962 & 89,960 & 67,880 & 67,880 & 67,878 \\
\hline Log likelihood & -39209.7141 & -39209.7140 & -38104.5924 & - & - & - \\
\hline Pseudo R2 & - & - & - & 0.1745 & 0.1798 & 0.2077 \\
\hline
\end{tabular}

Notes: Cluster-robust standard errors in parentheses, clustered by product.

* Indicate significance at the $10 \%$ level.

** Indicate significance at the 5\% level.

*** Indicate significance at the $1 \%$ level. 
increases fixed effects for regression. In columns (1)(3), we find $\beta_{1}$ to be positive and statistically significant at the $1 \%$ level in all three columns, and the results remain robust with more fixed effects. In particular, when controlling all fixed effects, we find $\beta_{1}$ to be positive and statistically significant at the $1 \%$ level in column (3). These results show that SPS measures have a significant inhibitory effect on the duration of Chinese agricultural exports at the product level. The SPS measures set by the importing country leads to an increase in the hazard rate by approximately $74.6 \%$ in column (3) of Table 2. In Columns (4)-(6) of Table 2, we report the regression results of the probit model, which are similar to those listed in columns (1)-(3) of Table 2. As column (6) shows, CCC regulation leads to an increase in the hazard rate of Chinese agricultural exports of approximately $73.9 \%$ while controlling all fixed effects. We also find that the coefficient shown in column (6) is approximately equal to that listed in column (3), confirming the impact of the SPS measures on the survival of China's agricultural exports.

The influence of the control variables used in this paper on export duration is consistent with existing research. The coefficient of the control variable lngdp is negative, indicating that the greater the economic scale of the importing country, the lesser the probability of China's agricultural products exiting the market. Large fluctuations in exchange rates are not conducive to the continuation of trade relations, and the coefficient is positive. The higher the initial trade value of agricultural products, the greater the confidence of the importer and exporter in the trade relationship is, causing trade to last longer with a negative coefficient. The more countries to which a product is exported, the lower the probability of the product exiting the market is, as it is more able to manage various export risks. The more types of products are exported to a certain market, the lower the probability of agricultural products exiting that market is, as exporters are more familiar with this market. The higher the trade value per capita, the lower the probability of agricultural products exiting the market is, as more demand denotes more benefits.

\section{Robustness checks}

In this section, we conduct a series of robustness checks on the afore-mentioned estimation results.

First, potential endogeneity in SPS measures due to reverse causality must be addressed. SPS measures may also be influenced by export levels in a particular sector. Previous empirical works in the literature on SPS measures acknowledge the potential for endogeneity. To address reverse causality concerns, we estimate our regressions while lagging the SPS measures notified by the importing country by one year: there is a small chance of SPS measures raised at $t-1$ being driven by exports at year t. As shown in columns (1)-(3) of Table

Table 3. Robustness results: lagged by one year and spell definition

\begin{tabular}{lccc|ccc}
\hline \multirow{2}{*}{ Variables } & \multicolumn{3}{c}{ one year time lag } & \multicolumn{3}{c}{ First spell } \\
\cline { 2 - 6 } & $(1)$ & $(2)$ & $(3)$ & $(4)$ & $(5)$ & $(6)$ \\
& outcome & outcome & outcome & outcome & outcome & outcome \\
\hline SPS_lag & $0.4461^{* *}$ & $0.4601^{* *}$ & $0.4850^{* *}$ & $0.9011^{* * *}$ & $0.9642^{* * *}$ & $0.9912^{* * * *}$ \\
lngdp & $(0.1970)$ & $(0.1970)$ & $(0.1980)$ & $(0.2312)$ & $(0.2321)$ & $(0.2331)$ \\
& $-0.1321^{* * *}$ & $-0.1341^{* * *}$ & $-0.2662^{* *}$ & $-0.1382^{* * *}$ & $-0.1442^{* * *}$ & $-0.2961^{* * *}$ \\
EXR & $(0.0099)$ & $(0.0100)$ & $(0.1341)$ & $(0.0092)$ & $(0.0093)$ & $(0.1131)$ \\
& $0.0000^{* * *}$ & $0.0000^{* * *}$ & $0.0001^{* *}$ & $0.0001^{* * *}$ & $0.0001^{* * *}$ & 0.0000 \\
tradevalue & $(0.0000)$ & $(0.0000)$ & $(0.0000)$ & $(0.0000)$ & $(0.0000)$ & $(0.0000)$ \\
& $-0.0000^{*}$ & $-0.0000^{*}$ & $-0.0000^{* *}$ & 0.0000 & 0.0000 & 0.0000 \\
per_value & $(0.0000)$ & $(0.0000)$ & $(0.0000)$ & $(0.0000)$ & $(0.0000)$ & $(0.0000)$ \\
& 0.0002 & 0.0003 & 0.0002 & 0.0002 & 0.0002 & 0.0002 \\
N_product & $(0.0002)$ & $(0.0002)$ & $(0.0002)$ & $(0.0003)$ & $(0.0003)$ & $(0.0003)$ \\
& $-0.0043^{* * *}$ & $-0.0044^{* * *}$ & $0.0014^{* *}$ & $-0.0053^{* * *}$ & $-0.0054^{* * *}$ & $0.0038^{* * *}$ \\
N_country & $(0.0001)$ & $(0.0001)$ & $(0.0006)$ & $(0.0001)$ & $(0.0001)$ & $(0.0006)$ \\
& $-0.0198^{* * *}$ & $-0.0206^{* * *}$ & $-0.0227^{* * *}$ & $-0.0231^{* * *}$ & $-0.0242^{* * *}$ & $-0.0258^{* * *}$ \\
percent_value & $(0.0003)$ & $(0.0004)$ & $(0.0004)$ & $(0.0003)$ & $(0.0004)$ & $(0.0004)$ \\
& $-0.9691^{* * *}$ & $-0.9471^{* * *}$ & $-1.2652^{* * *}$ & $-0.8353^{* * *}$ & $-0.8082^{* * *}$ & $-1.0090^{* * *}$ \\
Year FE & $(0.0890)$ & $(0.0896)$ & $(0.0933)$ & $(0.0816)$ & $(0.0819)$ & $(0.0849)$ \\
Product FE & Yes & Yes & Yes & Yes & Yes & Yes \\
Country FE & No & Yes & Yes & No & Yes & Yes \\
Constant & No & No & Yes & No & No & Yes \\
& $1.8871^{* * *}$ & $1.8960^{* * *}$ & 1.2290 & $2.6634^{* * *}$ & $3.1242^{* * *}$ & $8.5861^{* * *}$ \\
Observations & $(0.153)$ & $(0.227)$ & $(2.909)$ & $(0.140)$ & $(0.177)$ & $(2.286)$ \\
Log likelihood & 74,659 & 74,659 & 74,658 & 67,880 & 67,880 & 67,878 \\
& -27654.78 & -27517.928 & -26898.602 & -26039.099 & -25843.009 & -25087.687 \\
\hline
\end{tabular}

Notes: Cluster-robust standard errors in parentheses, clustered by product.

* Indicate significance at the 10\% level.

** Indicate significance at the 5\% level.

*** Indicate significance at the $1 \%$ level. 
3 , the results obtained using the lagged SPS dummy variable qualitatively confirm our main results for the effect of SPS measures on export survival probability. The coefficients of $\beta_{1}$ shown in columns (1)-(3) are consistent with our previous findings, implying an absence of reverse causality and hence alleviating concerns about the validity of our estimation strategy.

Second, the sub-samples also show the expected results. To address possible measurement errors in the statistics (where a trade relationship may be temporarily interrupted or end due to misreporting), for each product-country pair, only the first reported spell in the sample is considered ("first spell"). Besedeš and Prusa (2006b) proposed that the regression results are basically the same when the first spell of the same trade relationship is regarded as the only duration while multiple durations are regarded as independent durations. Therefore, we use the sample of the first spell to perform the robustness test, and the regression results are consistent with the benchmark regression results. As shown in column (4)-(6) of Table 3, the coefficients of $\beta_{1}$ in columns (4)-(6) are consistent with our previous findings, corroborating those of the full sample.

\section{Heterogeneity analysis}

To test whether SPS measure heterogeneity will have different effects on the survival probability of China's agricultural exports, we divided SPS measures into 5 categories according to the reasons for notification listed on the WTO website, and conducted an empirical analysis. The regression results are shown in Table 4.

The coefficients of SPS measures $\left(\beta_{1}\right)$ show obvious differences across columns (1) to (5) of Table 4 . The impact of SPS measures notified for different reasons on the survival probability of China's agricultural exports shows significant variations. Specifically, when the SPS is notified for concerns related to food safety, plant protection, and protection of humans from harm, SPS measures significantly increase the survival risk of China's agricultural exports. Among them, SPS measures protecting humans from animal/plant pests or diseases have the greatest impact on the duration of China's agricultural exports, increasing the probability of export interruption by $147 \%$. However, SPS measures adopted due to "animal health" and to "protect territory from other damage from pests" have no significant impact on the duration of China's agricultural exports.

In Table 5, we report the regression results classified by SPS type: whether an SPS measure involves emergency or regular notification. As column (2) shows, regular notification leads to an increase in the probability of exit interruption by approximately $77 \%$ at the HS-6 product level, while the impact of emergency notification on export duration is not significant. This may indicate that emergency notifications are only temporary, while regular notifications are more likely to be used as trade

Table 4. Results from the discrete-time hazard model for different notification reasons

\begin{tabular}{|c|c|c|c|c|c|}
\hline \multirow{3}{*}{ Variables } & food_safety & animal_health & plant_protection & protect_humans & protect_territory \\
\hline & (1) & (2) & (3) & (4) & (5) \\
\hline & outcome & outcome & outcome & outcome & outcome \\
\hline \multirow[t]{2}{*}{ SPS } & $0.7791 * * *$ & 0.3941 & $0.6180 * *$ & $1.4760 * * *$ & 0.6622 \\
\hline & $(0.261)$ & $(0.504)$ & $(0.305)$ & $(0.504)$ & $(0.415)$ \\
\hline \multirow[t]{2}{*}{$\operatorname{lngdp}$} & $-0.3501 * * *$ & $-0.3502 * * *$ & $-0.3501^{* * *}$ & $-0.3490 * * *$ & $-0.3500 * * *$ \\
\hline & $(0.0918)$ & (0.0918) & (0.0918) & (0.0918) & (0.0918) \\
\hline \multirow[t]{2}{*}{ EXR } & 0.0000 & 0.0000 & 0.0000 & 0.0000 & 0.0000 \\
\hline & $(0.0000)$ & $(0.0000)$ & $(0.0000)$ & $(0.0000)$ & $(0.0000)$ \\
\hline \multirow[t]{2}{*}{ tradevalue } & $-0.0000 * *$ & $-0.0000^{* *}$ & $-0.0000 * *$ & $-0.0000 * *$ & $-0.0000^{* *}$ \\
\hline & $(0.0000)$ & $(0.0000)$ & $(0.0000)$ & $(0.0000)$ & $(0.0000)$ \\
\hline \multirow[t]{2}{*}{ per_value } & 0.0001 & 0.0001 & 0.0001 & 0.0001 & 0.0001 \\
\hline & $(0.0002)$ & $(0.0002)$ & $(0.0002)$ & $(0.0002)$ & $(0.0002)$ \\
\hline \multirow[t]{2}{*}{ N_product } & $0.0012 * *$ & $0.0012^{* *}$ & $0.0012 * *$ & $0.0012 * *$ & $0.0012 * *$ \\
\hline & $(0.0005)$ & $(0.0005)$ & $(0.0005)$ & $(0.0005)$ & $(0.0005)$ \\
\hline \multirow[t]{2}{*}{ N_country } & $-0.0228 * * *$ & $-0.0228 * * *$ & $-0.0228 * * *$ & $-0.0228 * * *$ & $-0.0228 * * *$ \\
\hline & $(0.0003)$ & $(0.0003)$ & (0.0003) & $(0.0003)$ & $(0.0003)$ \\
\hline \multirow[t]{2}{*}{ percent_value } & $-0.9410 * * *$ & $-0.9411^{* * *}$ & $-0.9421^{* * *}$ & $-0.9410 * * *$ & $-0.9431 * * *$ \\
\hline & $(0.0699)$ & $(0.0700)$ & $(0.0700)$ & (0.0699) & $(0.0700)$ \\
\hline Year FE & Yes & Yes & Yes & Yes & Yes \\
\hline Product FE & Yes & Yes & Yes & Yes & Yes \\
\hline Country FE & Yes & Yes & Yes & Yes & Yes \\
\hline \multirow[t]{2}{*}{ Constant } & $8.7661^{* * *}$ & $8.733^{* * *}$ & $8.718^{* * *}$ & $8.719 * * *$ & $8.735^{* * *}$ \\
\hline & $(1.873)$ & $(1.873)$ & $(1.873)$ & $(1.874)$ & $(1.873)$ \\
\hline Observations & 89,960 & 89,960 & 89,960 & 89,960 & 89,960 \\
\hline Log likelihood & -38110.586 & -38113.843 & -38112.413 & -38111.314 & -38113.069 \\
\hline
\end{tabular}

Notes: Cluster-robust standard errors in parentheses, clustered by product.

* Indicate significance at the $10 \%$ level.

** Indicate significance at the 5\% level.

*** Indicate significance at the $1 \%$ level. 
Table 5. Results from the discrete-time hazard model for different notification types

\begin{tabular}{|c|c|c|}
\hline \multirow[b]{2}{*}{ Variables } & emergency & Regular \\
\hline & $\begin{array}{c}\text { (1) } \\
\text { outcome }\end{array}$ & $\begin{array}{c}\text { (2) } \\
\text { outcome }\end{array}$ \\
\hline \multirow[t]{2}{*}{ SPS } & 0.0059 & $0.7720 * * *$ \\
\hline & (1.0011) & $(0.1551)$ \\
\hline \multirow[t]{2}{*}{$\operatorname{lngdp}$} & $-0.3512^{* * *}$ & $-0.3480 * * *$ \\
\hline & $(0.0918)$ & $(0.0918)$ \\
\hline \multirow[t]{2}{*}{ EXR } & 0.0000 & 0.0000 \\
\hline & $(0.0000)$ & $(0.0000)$ \\
\hline \multirow[t]{2}{*}{ tradevalue } & $-0.0000 * *$ & $-0.0000 * *$ \\
\hline & $(0.0000)$ & $(0.0000)$ \\
\hline \multirow[t]{2}{*}{ per_value } & 0.0001 & 0.0001 \\
\hline & $(0.0002)$ & $(0.0002)$ \\
\hline \multirow[t]{2}{*}{ N_product } & $0.0012^{* *}$ & $0.0012 * *$ \\
\hline & $(0.0005)$ & $(0.0005)$ \\
\hline \multirow[t]{2}{*}{ N_country } & $-0.0228 * * *$ & $-0.0228 * * *$ \\
\hline & $(0.0003)$ & $(0.0003)$ \\
\hline \multirow[t]{2}{*}{ percent_value } & $-0.9410 * * *$ & $-0.9421 * * *$ \\
\hline & (0.0699) & $(0.0700)$ \\
\hline Year FE & Yes & Yes \\
\hline Product FE & Yes & Yes \\
\hline Country FE & Yes & Yes \\
\hline \multirow[t]{2}{*}{ Constant } & $8.7431 * * *$ & $8.6851^{* * *}$ \\
\hline & $(1.8732)$ & $(1.8740)$ \\
\hline Observations & 89,960 & 89,960 \\
\hline Log likelihood & -38114.113 & -38104.23 \\
\hline
\end{tabular}

Notes: Cluster-robust standard errors in parentheses, clustered by product.

* Indicate significance at the $10 \%$ level.

** Indicate significance at the 5\% level.

*** Indicate significance at the $1 \%$ level.

barriers to disrupt agricultural exports.

In Table 6, we report the regression results classified by the degree of agricultural products processing. The results show that the export duration of processed agricultural products is slightly less affected by SPS measures than primary agricultural products. In other words, SPS measures impose stronger restrictions on the export of primary agricultural products than on the export of processed agricultural products, which is consistent with the results of existing studies.

The regression results regarding the impact of SPS measures set by countries of different income levels on China's agricultural exports are reported in Table 7. We find that the SPS measures set by higher-income countries have a more negative impact on the duration of China's agricultural exports. SPS measures set by highincome countries will increase the probability of China's agricultural products exiting the market by $92.9 \%$ while SPS measures set by lower middle income countries has no significant impact. Due to the extremely small number of SPS measures set by low-income countries, the regression result coefficient is missing in column (4) of Table 7.

\section{CONCLUSIONS}

This paper, based on trade data on 6-digit HS code agroproducts of China's export for 2002 and 2017, explores whether the SPS measures reported by importing countries affect the export duration of China's agroproducts via discrete time survival analysis. It is found that SPS measures imposed by importing countries exert a significant negative impact on the export duration of China's agroproducts and to a large extent raises the probability of an interruption in China's agricultural exports, thereby increasing the survival risks of agricultural exports. In addition, different SPS measures have different impacts. Specifically, SPS measures adopted for reasons related to food safety, plant protection, and the protection of humans from animal and plant pests and diseases exert a more significant negative impact on export duration, but SPS measures set for reasons related to animal protection and the prevention of bioinvasion have no significant impact on survival probability. Regular notifications are more likely to interrupt China's agricultural exports that emergency notifications. In addition, prior findings of varied impacts of different products and countries are verified by this work.

SPS measures, as technical trade barriers, have had a considerable impact on China's agricultural export for a long time. To ensure the sustained export of agroproducts, China should first improve product technology laws and regulations as well as standard systems and enhance quality standards of Chinese agroproducts in responding to standard barriers imposed by importing countries. Over the long run, China should upgrade export struc- 
Table 6. Results from the discrete-time hazard model for products with different processing levels

\begin{tabular}{|c|c|c|c|c|c|c|}
\hline \multirow[b]{2}{*}{ Variables } & \multicolumn{3}{|c|}{ Primary agricultural products } & \multicolumn{3}{|c|}{ Processed agricultural products } \\
\hline & $\begin{array}{c}\text { (1) } \\
\text { outcome }\end{array}$ & $\begin{array}{c}\text { (2) } \\
\text { outcome }\end{array}$ & $\begin{array}{c}\text { (3) } \\
\text { outcome }\end{array}$ & $\begin{array}{c}\text { (1) } \\
\text { outcome }\end{array}$ & $\begin{array}{c}\text { (2) } \\
\text { outcome }\end{array}$ & $\begin{array}{c}(3) \\
\text { outcome }\end{array}$ \\
\hline SPS & $\begin{array}{c}0.7340^{* * * *} \\
(0.1793)\end{array}$ & $\begin{array}{c}0.7461 * * * \\
(0.1793)\end{array}$ & $\begin{array}{c}0.8162^{* * * *} \\
(0.1814)\end{array}$ & $\begin{array}{l}0.6264^{* *} \\
(0.2901)\end{array}$ & $\begin{array}{l}0.6281^{* *} \\
(0.2912)\end{array}$ & $\begin{array}{l}0.6130^{* *} \\
(0.2921)\end{array}$ \\
\hline $\operatorname{lngdp}$ & $\begin{array}{c}-0.1110^{* * * *} \\
(0.0102)\end{array}$ & $\begin{array}{c}-0.1140 * * * \\
(0.0103)\end{array}$ & $\begin{array}{c}-0.4201 * * * \\
(0.1251)\end{array}$ & $\begin{array}{c}-0.1461^{* * * *} \\
(0.0113)\end{array}$ & $\begin{array}{c}-0.1550 * * * \\
(0.0114)\end{array}$ & $\begin{array}{c}-0.3064 * * \\
(0.1370)\end{array}$ \\
\hline EXR & $\begin{array}{l}0.0000 * * \\
(0.0000)\end{array}$ & $\begin{array}{c}0.0000^{*} \\
(0.0000)\end{array}$ & $\begin{array}{c}0.0000 \\
(0.0000)\end{array}$ & $\begin{array}{l}0.0000 * * \\
(0.0000)\end{array}$ & $\begin{array}{l}0.0000 * * \\
(0.0000)\end{array}$ & $\begin{array}{l}-0.0000 \\
(0.0000)\end{array}$ \\
\hline tradevalue & $\begin{array}{l}-0.0000 * \\
(0.0000)\end{array}$ & $\begin{array}{l}-0.0000^{*} \\
(0.0000)\end{array}$ & $\begin{array}{c}-0.0000 * * \\
(0.0000)\end{array}$ & $\begin{array}{l}-0.0000 \\
(0.0000)\end{array}$ & $\begin{array}{l}-0.0000 \\
(0.0000)\end{array}$ & $\begin{array}{l}-0.0000 \\
(0.0000)\end{array}$ \\
\hline per_value & $\begin{array}{c}0.0002 \\
(0.0002)\end{array}$ & $\begin{array}{c}0.0000 \\
(0.0002)\end{array}$ & $\begin{array}{c}0.0001 \\
(0.0002)\end{array}$ & $\begin{array}{c}0.0020^{*} \\
(0.0011)\end{array}$ & $\begin{array}{l}0.0025^{* *} \\
(0.0011)\end{array}$ & $\begin{array}{l}0.0023^{* *} \\
(0.0011)\end{array}$ \\
\hline N_product & $\begin{array}{c}-0.0049 * * * \\
(0.0001)\end{array}$ & $\begin{array}{c}-0.0049 * * * \\
(0.0001)\end{array}$ & $\begin{array}{l}0.0011 * \\
(0.0006)\end{array}$ & $\begin{array}{c}-0.0045^{* * *} \\
(0.0002)\end{array}$ & $\begin{array}{c}-0.0045^{* * *} \\
(0.0002)\end{array}$ & $\begin{array}{c}0.0012 \\
(0.0008)\end{array}$ \\
\hline N_country & $\begin{array}{c}-0.0218^{* * * *} \\
(0.0004)\end{array}$ & $\begin{array}{c}-0.0229 * * * \\
(0.0005)\end{array}$ & $\begin{array}{c}-0.0258 * * * \\
(0.0005)\end{array}$ & $\begin{array}{c}-0.0198 * * * \\
(0.0004)\end{array}$ & $\begin{array}{c}-0.0200 * * * \\
(0.0004)\end{array}$ & $\begin{array}{c}-0.0216^{* * *} \\
(0.0004)\end{array}$ \\
\hline percent_value & $\begin{array}{c}-0.7230^{* * * *} \\
(0.0793)\end{array}$ & $\begin{array}{c}-0.6760 * * * \\
(0.0798)\end{array}$ & $\begin{array}{c}-0.8851 * * * \\
(0.0825)\end{array}$ & $\begin{array}{c}-0.7691^{* * * *} \\
(0.1261)\end{array}$ & $\begin{array}{c}-0.8402 * * * \\
(0.1270)\end{array}$ & $\begin{array}{c}-1.2180 * * * \\
(0.1340)\end{array}$ \\
\hline Year FE & Yes & Yes & Yes & Yes & Yes & Yes \\
\hline Product FE & No & Yes & Yes & No & Yes & Yes \\
\hline Country FE & No & No & Yes & No & No & Yes \\
\hline Constant & $\begin{array}{c}1.6300 * * * \\
(0.1581)\end{array}$ & $\begin{array}{c}2.0761 * * * \\
(0.1861)\end{array}$ & $\begin{array}{c}11.2422^{* * * *} \\
(2.4430)\end{array}$ & $\begin{array}{c}3.0131 * * * \\
(0.1730)\end{array}$ & $\begin{array}{c}3.4064 * * * \\
(0.1791)\end{array}$ & $\begin{array}{c}4.6360 \\
(2.9972)\end{array}$ \\
\hline Observations & 48,329 & 48,329 & 48,327 & 41,633 & 41,633 & 41,632 \\
\hline Log likelihood & -21826.897 & -21724.454 & -21115.684 & -17303.889 & -17203.104 & -16731.132 \\
\hline
\end{tabular}

Notes: Cluster-robust standard errors in parentheses, clustered by product.

* Indicate significance at the $10 \%$ level.

** Indicate significance at the $5 \%$ level.

*** Indicate significance at the $1 \%$ level.

tures of agroproducts, develop intensive processing systems for primary agroproducts, increase the value added of agroproducts, and avoid possible risks. In addition, China should distinguish between different types of SPS measures and leverage the role of industrial associations to track SPS measures of trade partners. The country can then show initiative in addressing SPS measures while avoiding the shock of importing countries' stringent technical barriers to exported agroproducts. Finally, due to the greater impact of SPS measures imposed by high-income countries on China's export duration, China should pay more attention and quickly respond to the standards of high-income countries to minimize the adverse impacts of changed standards on China's exports while maintaining exports to low-income countries.

\section{AUTHOR CONTRIBUTION}

Conceived and designed the methodology: Xuejun WANG, Koshi MAEDA and Xiaoqi ZHANG. Analyzed the data: Xiaoqi ZHANG and Xuejun WANG. Wrote the paper: Xiaoqi ZHANG, Xuejun WANG and Koshi MAEDA.

\section{ACKNOWLEDGEMENTS}

The study is supported by the Project of Philosophy and Social Science in Colleges and Universities of
Jiangsu Province (2019SJA0044); the Fundamental Research Funds for the Central Universities of Nanjing Agricultural University (SKCX2019005); the Priority Academic Program Development of Jiangsu Higher Education Institutions (PAPD), and China Center for Food Security Studies, Nanjing Agricultural University.

\section{REFERENCES}

Aka, J. 2017 Market approval of phytosanitary active substances in Europe: An empirical duration analysis. Food Policy, 68: $143-153$

Asche, F., A. L. Cojocaru, I. Gaasland and H. M. Straume 2018 Cod stories: Trade dynamics and duration for Norwegian cod exports. J. Commod Mark., 12: 71-79

Besedeš, T. and T. J. Prusa 2006a Ins, outs, and the duration of trade. Can. J. Econ., 39(1): 266-295

Besedeš, T. and T. J. Prusa 2006b Product differentiation and duration of US import trade. J. Int. Econ., 70: 339-358

Besedeš, T. and T. J. Prusa 2011 The role of extensive and intensive margins and export growth. J. Dev. Econ., 96: 371-379

Brenton, P., C. Saborowski and E. v. Vexkull 2010 What Explains the Low Survival Rate of Developing Country Export Flows? World Bank Econ. Rev., 24(3): 474-499

Chen, Y. B., L. D. Jiang and L. Cao 2012 Duration of China's Agricultural Product Export and Its Impact Factor Analysis. Iss. Agr. Econ., (11): 7-15

Crivelli, P. and J. Groeschl 2016 The Impact of Sanitary and Phytosanitary Measures on Market Entry and Trade Flows. World Econ., 39(3): 444-473

Gibson, M. J. and Q. Wang 2018 Sanitary and phytosanitary measures in Chinese agricultural exports: the role of trade inter- 
Table 7. Results from the discrete-time hazard model for countries with different income levels

\begin{tabular}{|c|c|c|c|c|}
\hline & High income & Upper middle income & Lower middle income & Low income \\
\hline Variables & $\begin{array}{c}\text { (1) } \\
\text { outcome }\end{array}$ & $\begin{array}{c}\text { (2) } \\
\text { outcome }\end{array}$ & $\begin{array}{c}\text { (3) } \\
\text { outcome }\end{array}$ & $\begin{array}{c}\text { (4) } \\
\text { outcome }\end{array}$ \\
\hline SPS & $\begin{array}{c}0.9291 * * * \\
(0.1933)\end{array}$ & $\begin{array}{c}0.5151^{*} \\
(0.2952)\end{array}$ & $\begin{array}{c}0.2440 \\
(0.5080)\end{array}$ & - \\
\hline $\operatorname{lngdp}$ & $\begin{array}{c}-0.3781 * * \\
(0.1567)\end{array}$ & $\begin{array}{c}-0.4041^{*} \\
(0.2082)\end{array}$ & $\begin{array}{c}-0.5342 * * \\
(0.2270)\end{array}$ & $\begin{array}{c}-0.6161 * * * \\
(0.2130)\end{array}$ \\
\hline EXR & $\begin{array}{l}0.0044 * * \\
(0.0020)\end{array}$ & $\begin{array}{c}0.0000 \\
(0.0000)\end{array}$ & $\begin{array}{c}0.0008 \\
(0.0022)\end{array}$ & $\begin{array}{c}-0.0011 * * \\
(0.0005)\end{array}$ \\
\hline tradevalue & $\begin{array}{l}-0.0000 \\
(0.0000)\end{array}$ & $\begin{array}{l}-0.0000 \\
(0.0000)\end{array}$ & $\begin{array}{c}-0.0000^{* *} \\
(0.0000)\end{array}$ & $\begin{array}{l}-0.0000 \\
(0.0000)\end{array}$ \\
\hline per_value & $\begin{array}{c}0.0006^{*} \\
(0.0003)\end{array}$ & $\begin{array}{l}-0.0002 \\
(0.0005)\end{array}$ & $\begin{array}{l}-0.0023 \\
(0.0020)\end{array}$ & $\begin{array}{c}0.0023 \\
(0.0034)\end{array}$ \\
\hline N_product & $\begin{array}{c}0.0002 \\
(0.0008)\end{array}$ & $\begin{array}{l}-0.0004 \\
(0.0013)\end{array}$ & $\begin{array}{c}0.0067 * * * \\
(0.0016)\end{array}$ & $\begin{array}{c}0.0185 * * * \\
(0.0033)\end{array}$ \\
\hline N_country & $\begin{array}{c}-0.0314^{* * *} \\
(0.0007)\end{array}$ & $\begin{array}{c}-0.0237 * * * \\
(0.0005)\end{array}$ & $\begin{array}{c}-0.0210 * * * \\
(0.0006)\end{array}$ & $\begin{array}{c}-0.0153 * * * \\
(0.0009)\end{array}$ \\
\hline percent_value & $\begin{array}{c}-0.8210 * * * \\
(0.0765)\end{array}$ & $\begin{array}{c}-2.0250^{* * * *} \\
(0.2251)\end{array}$ & $\begin{array}{c}-2.2672 * * * \\
(0.3625)\end{array}$ & $\begin{array}{l}-0.6536 \\
(0.4611)\end{array}$ \\
\hline Year FE & Yes & Yes & Yes & Yes \\
\hline Product FE & Yes & Yes & Yes & Yes \\
\hline Country FE & Yes & Yes & Yes & Yes \\
\hline Constant & $\begin{array}{l}4.747^{*} \\
(2.665)\end{array}$ & $\begin{array}{c}18.79 * * * \\
(5.388)\end{array}$ & $\begin{array}{l}12.53^{*} \\
(7.576)\end{array}$ & $\begin{array}{c}-67.25^{* * *} \\
(25.93)\end{array}$ \\
\hline Observations & 42,631 & 27,855 & 15,055 & 4,419 \\
\hline Log likelihood & -14809.941 & -12688.304 & -7643.8228 & -2418.4744 \\
\hline
\end{tabular}

Notes: Cluster-robust standard errors in parentheses, clustered by product.

* Indicate significance at the $10 \%$ level.

** Indicate significance at the $5 \%$ level.

*** Indicate significance at the $1 \%$ level.

mediaries. Appl. Econ., 50(27): 3007-3015

Henson, S. and R. Loader 2001 Barriers to Agricultural Exports from Developing Countries: The Role of Sanitary and Phytosanitary Requirements. World Dev., 29(1): 85-102

Hess, W. and M. Persson 2011 Exploring the duration of EU imports. Rev. World Econ., 147(4): 665-692

Nitsch, V. 2009 Die another day: duration in German import trade. Rev. World Econ., 145: 133-154

Peterson, E. B., J. H. Grant and J. Rudi-Polloshka 2018 Survival of the fittest: export duration and failure into united states fresh fruit and vegetable markets. Am. J Agr. Econ., 100(1): 23-45

Shang, X. and G. T. Tonsor, 2019 Sanitary and phytosanitary regulations and international red meat trade, Brit. Food J., 121(10): 2309-2321

Wilson, J. S. and T. Otsuki 2004 To spray or not to spray: pesticides, banana exports, and food safety. Food Policy, 29(2): $131-146$ 